\title{
Long-Term Prognosis in Young Patients with Stable Coronary Disease: Ten-Year Follow-up of Percutaneous Coronary Intervention
}

\author{
Igor Ribeiro de Castro Bienert', Expedito E. Ribeiro ${ }^{2}$, Luiz J. Kajita ${ }^{3}$, Marco Antonio Perin ${ }^{4}$, \\ Carlos A. H. Campos ${ }^{5}$, Fabio Trentin ${ }^{6}$, Pedro Alves Lemos ${ }^{7}$
}

\begin{abstract}
Background: The long-term prognostic implications of stable coronary artery disease (CAD) in young patients are currently unknown. The objective of this study was to evaluate the prognosis of young adult patients diagnosed with stable CAD who were treated by percutaneous coronary intervention $(\mathrm{PCl})$ and followed for up to ten years. Methods: The study population consisted of young patients (age below the $10^{\text {th }}$ percentile) from a group of 1,394 consecutive patients treated for stable CAD using the percutaneous approach. The patients' characteristics were prospectively collected. After the procedure, outpatient follow-up was conducted, including the analysis of the electronic medical records and telephone contact, whenever required. The primary outcome was overall mortality, and the secondary outcome was cardiovascular mortality. Results: A total of 140 patients were selected, with a mean age of $43.7 \pm 4$ years (ranging from 26 to 48 years), who were predominantly males (76.4\%). Diabetes mellitus was present in approximately one fifth of the patients, and half of them had a previous myocardial infarction. Patients were followed for an average of $94.6 \pm 36.2$ months, and the overall mortality after ten years was $6 \%$, with a cardiac mortality of $5.3 \%$. All patients who died had a successful index procedure, and only one of the cases did not have a previous myocardial
\end{abstract}

\section{RESUMO}

\section{Prognóstico Tardio em Jovens com Coronariopatia \\ Estável: Evolução em 10 Anos após Intervenção Coronária Percutânea}

Introdução: Atualmente são ainda desconhecidas as implicações prognósticas tardias da doença arterial coronária (DAC) estável em pacientes jovens. O objetivo deste trabalho foi avaliar o prognóstico de pacientes adultos jovens com diagnóstico de DAC estável, tratados por meio de intervenção coronária percutânea (ICP) e acompanhados por até 10 anos. Métodos: A população do estudo foi constituída por pacientes jovens (idade abaixo do 10 o percentil) de um grupo de 1.394 pacientes consecutivos tratados para DAC estável por via percutânea. As características dos pacientes foram coletadas prospectivamente. Após o procedimento foi realizado seguimento ambulatorial, com análise do prontuário hospitalar eletrônico e contato telefônico, quando necessário. O desfecho primário foi a mortalidade geral e o desfecho secundário, a mortalidade cardiovascular. Resultados: Foram selecionados 140 pacientes, com média de idade de $43,7 \pm 4$ anos (mínimo de 26 anos e máximo de 48 anos), predominantemente do sexo masculino $(76,4 \%)$. Diabetes melito estava presente em aproximadamente um quinto dos pacientes e metade apresentava infarto prévio. Os pacientes foram seguidos por uma média de 94,6 6 36,2 meses e a mortalidade geral no

\footnotetext{
1 Specialist in Cardiology. Physician; Technical Director of the Interventionist Cardiology Service of Hospital das Clínicas da Faculdade Estadual de Medicina de Marília. Marília, SP, Brazil.

${ }^{2}$ Tenured Professor. Physician; Supervisor of the Interventionist Cardiology Service of Instituto do Coração do Hospital das Clínicas da Faculdade de Medicina da Universidade de São Paulo. São Paulo, SP, Brazil. ${ }^{3}$ Specialist in Interventionist Cardiology. Physician; Supervisor of the Interventionist Cardiology Service of Instituto do Coração do Hospital das Clínicas da Faculdade de Medicina da Universidade de São Paulo. São Paulo, SP, Brazil.

4 Tenured Professor. Physician; Supervisor of the Interventionist Cardiology Service of Instituto do Coração do Hospital das Clínicas da Faculdade de Medicina da Universidade de São Paulo. São Paulo, SP, Brazil.

${ }^{5}$ Specialist in Interventionist Cardiology. Assistant physician at the Interventionist Cardiology Service of Instituto do Coração do Hospital
}

\begin{abstract}
das Clínicas da Faculdade de Medicina da Universidade de São Paulo. São Paulo, SP, Brazil.

${ }^{6}$ Resident Physician at the Interventionist Cardiology Service of Instituto do Coração do Hospital das Clínicas da Faculdade de Medicina da Universidade de São Paulo. São Paulo, SP, Brazil.

7 Tenured Professor. Technical Director of the Interventionist Cardiology Service at Instituto do Coração do Hospital das Clínicas da Faculdade de Medicina da Universidade de São Paulo. São Paulo, SP, Brazil.
\end{abstract}

Correspondence to: Igor Ribeiro de Castro Bienert. Rua Aziz Atallah s/n - Bairro Fragata - Marília, SP, Brasil - CEP 17519-101

E-mail: bienert@famema.br

Received on: 3/26/2012 • Accepted on: 6/5/2012 
infarction. Conclusions: In this clinical practice, young patients with chronic CAD treated by $\mathrm{PCl}$ had good late prognosis.

DESCRIPTORS: Angioplasty. Coronary disease. Age groups. Prognosis.

$S$ everal studies defining the role of percutaneous coronary intervention $(\mathrm{PCl})$ in coronary artery disease (CAD) have discussed the individualised indication of this procedure, aiming to better identify patients who will benefit from interventional treatment. However, due to the higher prevalence of CAD after the sixth decade of life, ${ }^{1}$ much of the available scientific information about the disease has come from studies in which young patients are underrepresented. ${ }^{2,3}$ Few studies have been focused on the implications of CAD in young populations, ${ }^{2-6}$ and even these studies have focused on the disease presenting as an acute coronary syndrome. ${ }^{3,6}$

The prognostic implications of CAD in its stable form are still currently unknown in young patients. In theory, the early onset of the disease could indicate a worse long-term prognosis, due to the possible increased aggressiveness of the disease that led to its manifestation at a young age. Conversely, diagnosis at an early stage could represent an opportunity for clinical actions to prevent atherosclerotic progression.

The objective of this study was to evaluate the clinical characteristics and late mortality in a population of young patients with stable CAD treated by percutaneous coronary intervention.

\section{METHODS}

\section{Study population}

The study population was retrospectively selected from a cohort of 1,394 patients living in the State of São Paulo who were consecutively admitted between 1998 and 2003 by the Brazilian Unified Health System (Sistema Único de Saúde - SUS) for the percutaneous treatment of chronic stable coronary disease, defined as the presence of angina or documented silent ischemia with no acute events in the previous 30 days. Data collection was approved by the ethics committee of the institution.

The age range of the population treated in this centre below the $10^{\text {th }}$ percentile for age was defined as young, which totalled 140 individuals. The clinical seguimento de 10 anos foi de $6 \%$, com mortalidade cardíaca de $5,3 \%$. Todos os pacientes que morreram obtiveram sucesso no procedimento inicial e apenas um dos casos não apresentava infarto prévio. Conclusões: Em nossa prática clínica, pacientes jovens com coronariopatia crônica tratados com ICP mostraram ter bom prognóstico tardio.

DESCRITORES: Angioplastia. Doença das coronárias. Grupos etários. Prognóstico. Stents. Anticoagulantes. Fondaparinux.

and angiographic characteristics of the study population were prospectively registered for all patients. The intervention technique and strategy were decided by the hemodynamics specialist in charge of each case. Only bare-metal stents were used.

\section{Clinical follow-up}

The follow-up and recording of in-hospital mortality were obtained for all patients after the index procedure. The follow-up evaluation after hospital discharge was performed at the outpatient cardiology clinic of the institution and verified through the analysis of hospital records or by telephone contact, when necessary. The cause of death was classified as cardiac or non-cardiac. The primary endpoint of this study was the occurrence of death from any cause, and cardiac mortality was assessed as a secondary outcome.

Cardiac death was defined as any death except that with an unequivocal non-cardiac cause, as demonstrated by data in the medical file or an autopsy or as reported on the death certificate.

\section{Statistical analysis}

Categorical variables were shown as percentages, and continuous variables were shown as means and standard deviations. Comparison between categorical variables was performed using the chi-squared test. The cumulative incidence of death was estimated according to the Kaplan-Meier method. Patients lost to follow-up were considered at risk until the date of the last contact, from which point they were eliminated from the analysis.

\section{RESULTS}

Patients had a mean age of $43.7 \pm 4$ years (minimum 26 years and maximum 48 years) and were predominantly male $(76.4 \%)$. At the time of the index procedure, one quarter of the patients were obese (defined as body mass index $\left.[\mathrm{BMI}]>30 \mathrm{~kg} / \mathrm{m}^{2}\right)$, and two thirds $(66.4 \%)$ had dyslipidaemia. One third (31.4\%) were active smokers, and diabetes was present in approximately one fifth 
$(20.7 \%)$. Half of the patients $(52.1 \%)$ had experienced a previous myocardial infarction, and most patients $(87.9 \%)$ were referred due to complaints of exertional angina. The clinical and procedural characteristics are shown in Table 1.

At admission, one quarter (26.4\%) of the patients received beta-blockers, and the same proportion used angiotensin-converting enzyme inhibitors. Approximately one third (35\%) used statins. Over half of the patients $(57.1 \%)$ were using aspirin when they were referred to treatment, which did not differ between

TABLE 1

Clinical and Procedural Characteristics

\begin{tabular}{|c|c|}
\hline \multicolumn{2}{|l|}{ Variable } \\
\hline Male gender, \% & 76.4 \\
\hline Diabetes, \% & 20.7 \\
\hline Dyslipidaemia, \% & 66.4 \\
\hline Arterial hypertension, \% & 61.4 \\
\hline Obesity*, \% & 25 \\
\hline Previous AMI, \% & 52.1 \\
\hline Active smoking, \% & 31.4 \\
\hline $\mathrm{CHF}, \%$ & 13.6 \\
\hline Family history, \% & 23.6 \\
\hline \multicolumn{2}{|l|}{ Previous intervention, $\%$} \\
\hline Previous $\mathrm{PCl}$ & 11.4 \\
\hline Previous CABG & 7.1 \\
\hline Left ventricular ejection fraction ${ }^{\dagger}, \%$ & $49.9 \pm 13.9$ \\
\hline \multicolumn{2}{|l|}{ Clinical presentation, $\%$} \\
\hline Exertional angina & 87.9 \\
\hline Silent ischemia & 10 \\
\hline \multicolumn{2}{|l|}{ Procedure, \% } \\
\hline $\mathrm{PCl}$ with stent & 87.9 \\
\hline Success $^{\ddagger}, \%$ & 92.1 \\
\hline Stents per patient & $1.18 \pm 0.69$ \\
\hline \multicolumn{2}{|l|}{ Arterial pattern, \% } \\
\hline One-vessel & 50 \\
\hline Two-vessel & 36.43 \\
\hline Three-vessel & 13.57 \\
\hline LCA & 1.43 \\
\hline \multicolumn{2}{|c|}{ 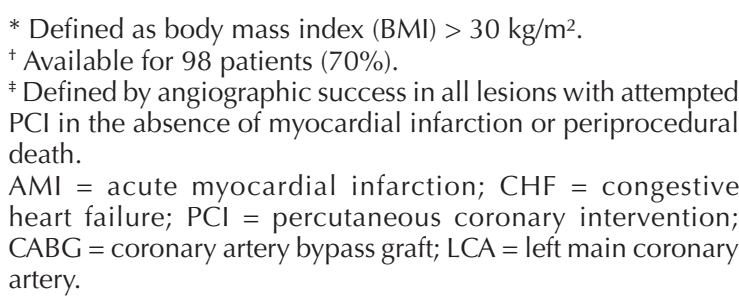 } \\
\hline
\end{tabular}

patients with and without prior acute myocardial infarction $(58.9 \%$ vs. $55.2 \%$; $\mathrm{P}=0.79)$. Regarding statins, their use was also reduced in patients in secondary prevention after acute myocardial infarctions and in patients in primary prevention $(35.6 \%$ vs. $34.3 \%$; $\mathrm{P}=0.98)$. Coronary stents were used in the majority of patients $(87.9 \%)$, and $1.18 \pm 0.69$ stents were implanted per patient; all stents used were bare-metal.

Patients were followed for a mean of $94.6 \pm 36.2$ months, and the overall mortality rate found in the following ten years was $6 \%$ (five cases) (Figure 1), with a cardiac mortality of $5.3 \%$ (one case of non-cardiac death) (Figure 2). There were no cases of death during hospitalisation. The only case of non-cardiac death was due to suicide at 30 days of follow-up. The observed low incidence of primary and secondary outcomes did not allow for the the analysis of independent risk predictors. All cases of death had successful initial procedures, only one case had diabetes, and only one

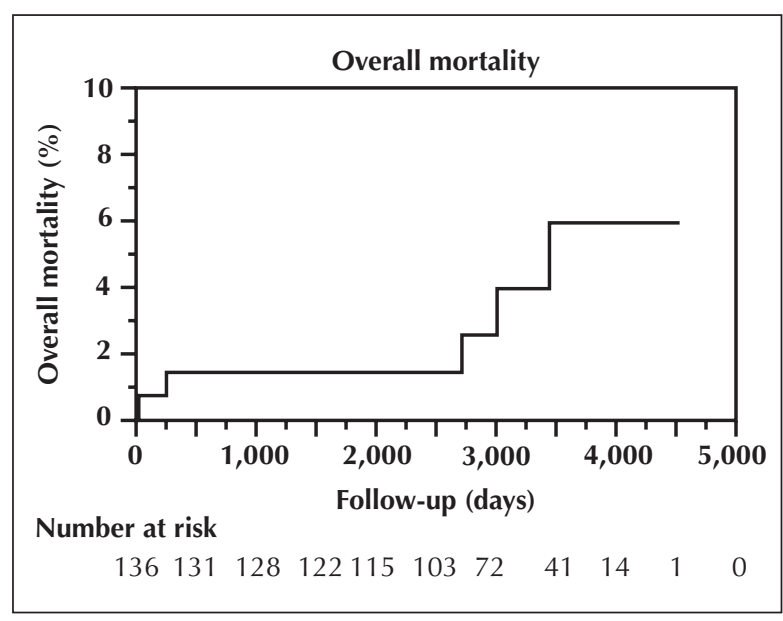

Figure 1 - Overall mortality curve.

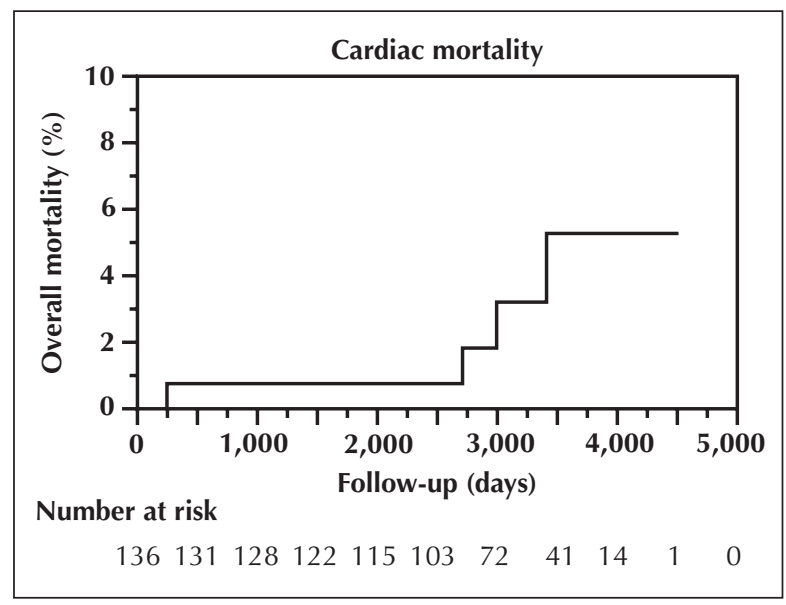

Figure 2 - Cardiac mortality curve. 
case of death had no previous myocardial infarction. Among the deaths due to cardiac causes, the mean follow-up was $78.5 \pm 47.5$ months. Two cases were described as having acute myocardial infarction as the primary cause of death, one case of sudden death was described during a haemodialysis session, and one case was considered to have an unknown aetiology. It was not possible to establish a causal connection between the index procedures and the later deaths in the reported cases.

\section{DISCUSSION}

The present study aimed to evaluate the hypothesis that the diagnosis of chronic stable coronary disease at a young age would be associated with a poor late prognosis. In this study, an overall mortality of $6 \%$ after ten years of evolution was observed. While a formal comparison is not possible, this result does not express a considerably increased risk of death. Although a more consistent analysis is not allowed, it is noteworthy that among the patients who died, almost all had experienced an acute myocardial infarction prior to the percutaneous treatment. The mortality of stable CAD in young individuals treated by percutaneous intervention does not suggest the presence of excessive malignancy. Compared with the expected mortality rate for the mean age of this cohort in the general population (subjects with a mean age of 43 years at ten years follow-up), an overall mortality of $5.49 \%$ is expected, according to data from the Brazilian Institute of Geography and Statistics (Instituto Brasileiro de Geografia e Estatística - IBGE). ${ }^{7}$

Few studies have been conducted on stable CAD in a young population, and the results available in the literature are, in general, similar to those found in the present study. Another study conducted in a young population submitted to intervention found a mortality rate of $6.2 \%$ after a five-year follow-up, even though most patients in this study were admitted with unstable angina. ${ }^{6}$ In a recent study, the analysis of a population of young patients with premature coronary disease after percutaneous intervention showed a mortality between $6 \%$ and $7 \%$ at five-year follow-up; $63 \%$ of this sample of patients was treated after myocardial infarction and $66 \%$ were treated at urgent care or emergency departments. ${ }^{4}$

Although the mortality rate found in the study did not demonstrate an increased risk, the authors emphasise that this is not a study of the natural history of coronary heart disease. It is reasonable to hypothesise that, although aggressive, the appropriate treatment of coronary disease in this population could dramatically reduce the mortality rate compared with what is otherwise observed. Although the number of patients submitted to adequate initial pharmacological treatment when referred for invasive treatment was low (slightly over half of the patients were taking aspirin and one third were using statins, with no difference between patients with and without previous infarction), PCI may represent a milestone of treatment optimisation and encourage adherence to treatment. Even if such a claim cannot be formally demonstrated by the present findings, it is likely that the association of optimised clinical and percutaneous treatments is responsible for the benefit of reduced mortality in this young population.

To better assess the prognosis in relation to the general population, the investigation was expanded beyond the cardiovascular field and identified, in indexed journals in the Brazilian literature, comparative analysis cohorts of chronic diseases, all of a similar age range as the present sample, with mortality follow-up on an outpatient basis (Figure 3).

Diseased with aggressive behaviour, such as in patients with chronic kidney disease on early dialytic therapy with a mean age of 47.8 years, reached a mortality rate of $36.5 \%$ in three years. When associated with diabetes mellitus, the mortality was $74.5 \%{ }^{8}$ Neoplasms are undoubtedly conditions of great malignancy in young patients; patients with breast cancer ${ }^{9}$ had a mortality of $25 \%$, and patients with cervical cancer had a mortality of $20.4 \%$, both after five years of follow-up. ${ }^{10}$ The analysis of stable outpatients with the human immunodeficiency virus (HIV) with a mean age of 36 years identified a mortality rate of $24.2 \%$ in eight years of follow-up. ${ }^{11}$ Even diseases sometimes regarded as lower risk compared with coronary disease were shown to be more aggressive, such as outpatients

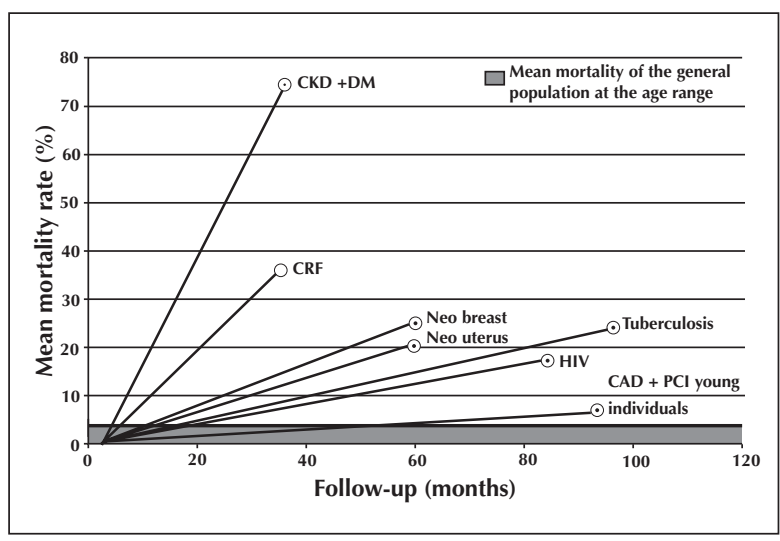

Figure 3 - Chart comparing the mortality in outpatient cohorts at similar age ranges. The delimited line refers to the mean mortality in the age group of the general population, according to data from the Brazilian Institute of Geography and Statistics (Instituto Brasileiro de Geografia e Estatística - IBGE). The mortality data were collected as available from SciELO/PubMedindexed literature. $\mathrm{CAD}+\mathrm{PCl}=$ coronary artery disease treated by percutaneous coronary intervention; $\mathrm{DM}=$ diabetes mellitus; $\mathrm{HIV}=$ human immunodeficiency virus; $\mathrm{CKD}=$ chronic kidney disease (initial dialytic phase); Neo breast $=$ unspecified breast cancer; Neo uterus $=$ unspecified cervical neoplasia. 
aged between 40 and 49 years with tuberculosis, who exhibited a mortality rate of $17.4 \%$ in seven years. ${ }^{12}$

\section{Study limitations}

This study was a single-centre registry, and limitations concerning this factor should be considered. This observational analysis after intervention did not attempt to compare therapeutics or even to predict the impact of specific treatment, whether percutaneous or drug therapy, but rather to describe the clinical evolution of this population of 140 patients with an unusual presentation of CAD, considering that analyses related to this age group are not common in the literature, especially when the disease is not in its acute form. It is also noteworthy that the authors did not have access to the period prior to the CAD diagnosis for analysis in these patients, as they were included in the series when referred for interventional treatment. Despite this limitation, the follow-up after percutaneous intervention therapy may represent a milestone of standardisation for the early follow-up of this population.

\section{CONCLUSIONS}

The primary finding of the present study was that young patients with chronic coronary artery disease treated by percutaneous coronary intervention in clinical practice have a good prognosis.

In a context in which issues concerning the effectiveness of the delayed treatment of coronary heart disease arise, these findings may ultimately contribute to the selection of a therapeutic strategy and an understanding of the prognosis in patients with early disease manifestation.

\section{CONFLICTS OF INTEREST}

The authors declare no conflicts of interest.

\section{REFERENCES}

1. Sposito AC, Caramelli B, Fonseca FA, Bertolami MC, Afiune Neto A, Souza AD, et al. IV Brazilian guideline for dyslipidemia and atherosclerosis prevention: Department of Atherosclerosis of Brazilian Society of Cardiology. Arq Bras Cardiol. 2007;88 Suppl 1:2-19.

2. Preis SR, Hwang SJ, Coady S, Pencina MJ, D'Agostino RB Sr, Savage PJ, et al. Trends in all-cause and cardiovascular disease mortality among women and men with and without diabetes mellitus in the Framingham Heart Study, 1950 to 2005. Circulation. 2009;119(13):1728-35.

3. Conti RA, Solimene MC, Luz PL, Benjó AM, Lemos Neto PA, Ramires JAF. Comparison between young males and females with acute myocardial infarction. Arq Bras Cardiol. 2002; 79(5):510-25

4. Khawaja FJ, Rihal CS, Lennon RJ, Holmes DR, Prasad A. Temporal trends (over 30 years), clinical characteristics, outcomes, and gender in patients $<50$ years of age having percutaneous coronary intervention. Am J Cardiol. 2011;107(5):668-74.

5. Gregg EW, Cheng YJ, Cadwell BL, Imperatore G, Williams DE, Flegal KM, et al. Secular trends in cardiovascular disease risk factors according to body mass index in US adults. JAMA. 2005;293(15):1868-74.

6. Webb JG, Myler RK, Shaw RE, Anwar A, Stertzer SH. Coronary angioplasty in young adults: initial results and late outcome. J Am Coll Cardiol. 1990;16(7):1569-74.

7. Instituto Brasileiro de Geografia e Estatística (IBGE). Tábuas completas de mortalidade. Rio de Janeiro; 2010 [cited 14 June 2011]. Available from: http://www.ibge.gov.br/home/estatistica/ populacao/tabuadevida/2010/default.shtm

8. D'Avila R, Guerra EMM, Rodrigues CIS, Fernandes FA, Cadaval RAM, Almeida FA. Sobrevida de pacientes renais crônicos em diálise peritoneal e hemodiálise. J Bras Nefrol. 1999;21(1):13-21.

9. Mendonça GAS, Silva AM, Caula WM. Características tumorais e sobrevida de cinco anos em pacientes com câncer de mama admitidas no Instituto Nacional de Câncer, Rio de Janeiro, Brasil. Cad Saúde Pública. 2004;20(5):1232-9.

10. Mendonça VG, Lorenzato FRB, Mendonça GJ, Menezes TG, Guimarães MJB. Mortalidade por câncer do colo do útero: características sociodemográficas das mulheres residentes na cidade de Recife, Pernambuco. Rev Bras Ginecol Obstet. 2008; 30(5):248-55.

11. Helena ETS, Mafra ML, Simes M. Fatores associados à sobrevida de pessoas vivendo com AIDS no Município de Blumenau, Estado de Santa Catarina, Brasil, 1997-2004. Epidemiol Serv Saúde. 2009;18(1):45-53.

12. Oliveira HB, Marin-Léon L, Cardoso JC. Perfil de mortalidade de pacientes com tuberculose relacionada à comorbidade tuberculose-AIDS. Rev Saúde Pública. 2004;38(4):503-10. 